\title{
Combined Pancreas and Kidney Transplantation Normalizes Protein Metabolism in Insulin-dependent Diabetic-Uremic Patients
}

\author{
Livio Luzi, " Alberto Battezzati, * Gianluca Perseghin, * Elda Bianchi, * lleana Terruzzi, " Donatella Spotti, * Sandro Vergani, \\ Antonio Secchi, * Ennio La Rocca, " Giovanni Ferrari," Carlo Staudacher," Renato Castoldi," \\ Valerio Di Carlo," and Guido Pozza* \\ Departments of *Internal Medicine, ${ }^{\$}$ Surgery, and ${ }^{\ddagger}$ Ophthalmology, San Raphael Scientific Institute, University of Milan, 20132 \\ Milan, Italy
}

\section{Abstract}

In order to assess the combined and separate effects of pancreas and kidney transplant on whole-body protein metabolism, 9 insulin-dependent diabetic-uremic patients (IDDUP), 14 patients after combined kidney-pancreas transplantation (KP$T x$ ), and 6 insulin-dependent diabetic patients with isolated kidney transplant (K-Tx), were studied in the basal postabsorptive state and during euglycemic hyperinsulinemia (study 1). $\left[1-{ }^{14} \mathrm{C}\right]$ Leucine infusion and indirect calorimetry were utilized to assess leucine metabolism. The subjects were studied again with a combined infusion of insulin and amino acids, given to mimic postprandial amino acid levels (study 2 ). In the basal state, IDDUP demonstrated with respect to normal subjects (CON): (a) higher free-insulin concentration (17.8 \pm 2.8 vs. $6.8 \pm 1.1 \mu \mathrm{U} / \mathrm{ml}, P<0.01)(107 \pm 17$ vs. $41 \pm 7 \mathrm{pM})$; (b) reduced plasma leucine ( $92 \pm 9$ vs. $124 \pm 2 \mu \mathrm{M}, P<0.05)$, branched chain amino acids (BCAA) $(297 \pm 34$ vs. $416 \pm 10 \mu \mathrm{M}$, $P<0.05)$, endogenous leucine flux (ELF) $(28.7 \pm 0.8 \mathrm{vs}$. $\left.39.5 \pm 0.7 \mu \mathrm{mol} \cdot \mathrm{m}^{-2} \cdot \mathrm{min}^{-1}, P<0.01\right)$ and nonoxidative leucine disposal (NOLD) $\left(20.7 \pm 0.2\right.$ vs. $32.0 \pm 0.7 \mu \mathrm{mol} \cdot \mathrm{m}^{-2}$. $\min ^{-1}, P<0.01$ ); (c) similar leucine oxidation (LO) $(8.0 \pm 0.1$ vs. 7.5 $\left.\pm 0.1 \mu \mathrm{mol} \cdot \mathrm{m}^{-2} \cdot \mathrm{min}^{-1} ; P=\mathrm{NS}\right)$. Both KP-Tx and KTx patients showed a complete normalization of plasma leucine $(116 \pm 5$ and $107 \pm 9 \mu M)$, ELF $(38.1 \pm 0.1$ and $38.5 \pm 0.9$ $\left.\mu \mathrm{mol} \cdot \mathrm{m}^{-2} \cdot \mathrm{min}^{-1}\right)$, and NOLD $(28.3 \pm 0.6$ and $31.0 \pm 1.3$ $\left.\mu \mathrm{mol} \cdot \mathrm{m}^{-2} \cdot \min ^{-1}\right)(P=$ NS vs. CON $)$. During hyperinsulinemia (study 1 ), IDDUP showed a defective decrease of leucine (42\% vs. 53\%; $P<0.05)$, BCAA (38\% vs. 47\%, $P<0.05)$, ELF (28\% vs. $33 \%, P<0.05)$, and LO (0\% vs. $32 \%, P<0.05)$ with respect to $\mathrm{CON}$. Isolated kidney transplant reverted the defective inhibition of ELF (34\%, P = NS vs. CON) of IDDUP, but not the inhibition of $\mathrm{LO}(18 \%, P<0.05$ vs. CON $)$ by insulin. Combined kidney and pancreas transplantation normalized all kinetic parameters of insulin-mediated protein turnover. During combined hyperinsulinemia and hyperaminoacidemia (study 2), IDDUP showed a defective stimulation of NOLD (27.9 \pm 0.7 vs. $36.1 \pm 0.8 \mu \mathrm{mol} \cdot \mathrm{m}^{-2} \cdot \min ^{-1}, P<0.01$ compared

Address correspondence to Dr. Livio Luzi at his current address: Section of Diabetes and Metabolism, Division of Endocrinology-Hypertension, Brigham and Women's Hospital, 221 Longwood Avenue, Boston, MA 02115. 1993.

Received for publication 2 April 1993 and in revised form 8 October

J. Clin. Invest.

(c) The American Society for Clinical Investigation, Inc.

$0021-9738 / 94 / 05 / 1948 / 11 \$ 2.00$

Volume 93, May 1994, 1948-1958 to $\mathrm{CON})$, which was normalized by transplantation $(44.3 \pm 0.8$ $\left.\mu \mathrm{mol} \cdot \mathrm{m}^{-2} \cdot \mathrm{min}^{-1}\right)$. (J. Clin. Invest. 1994. 93:1948-1958.) Key words: diabetes mellitus • uremia • kidney transplant • kidney-pancreas transplant • protein turnover

\section{Introduction}

Both diabetes mellitus and chronic uremia determine profound alterations of whole-body protein metabolism (1-3). In the fasting state, poorly controlled diabetic patients are characterized by negative nitrogen balance, increased blood amino acid concentrations, and increased protein turnover and oxidation rates, as assessed by commonly employed isotope techniques (4-6). In contrast, patients with chronic uremia usually present reduced blood amino acid concentrations and reduced whole-body leucine turnover and oxidation rates (7). The result of these metabolic alterations is a negative nitrogen balance. Furthermore, in the insulin-stimulated condition, both diabetes mellitus (4) and chronic uremia (8) are characterized by insulin resistance with respect to glucose metabolism, whereas the insulin effect on protein metabolism is normal. This suggests that the defect in insulin action is at postreceptorial sites in both diseases.

Isolated kidney and combined kidney-pancreas transplantation constitute valid therapeutic approaches in the treatment of insulin-dependent diabetic patients who develop end-stage renal failure. Previous reports already emphasized the importance of co-transplanting the pancreas along with the kidney, in order to obtain a near normalization of glucose metabolism (9-15). The effect of kidney-pancreas transplantation on whole-body protein metabolism is still unknown. An additional problem is constituted by the need to administer chronic immunosuppressive therapy in diabetic patients after kidney and pancreas transplantation. The specific aims of this work are $(a)$ to assess the effect of isolated kidney transplant and combined kidney-pancreas transplantation on basal leucine turnover and oxidation rates (which are an estimate of both protein catabolism and protein synthesis), $(b)$ to assess the effect of acute hyperinsulinemia on leucine/protein metabolism before and after isolated kidney and combined kidneypancreas transplantation, $(c)$ to study the effect of combined hyperinsulinemia/hyperaminoacidemia on protein synthesis before and after kidney-pancreas transplantation, $(d)$ to determine the effect of chronic immunosuppressive therapy per se on leucine/protein metabolism in patients with posterior chronic uveitis (localized ocular disease without systemic disease). Our results demonstrate that combined kidney-pancreas transplantation completely reverts the alterations of amino acid/protein metabolism in diabetic-uremic patients. 


\begin{tabular}{|c|c|c|c|c|c|}
\hline & $\begin{array}{l}\text { Group 1 } \\
\text { (IDDUP) }\end{array}$ & $\begin{array}{l}\text { Group } 2 \\
\text { (KP-Tx) }\end{array}$ & $\begin{array}{l}\text { Group } 3 \\
\text { (K-Tx) }\end{array}$ & $\begin{array}{l}\text { Group } 4 \\
\text { (CU) }\end{array}$ & $\begin{array}{l}\text { Group } 5 \\
\text { (CON) }\end{array}$ \\
\hline Number & 9 & 14 & 6 & 5 & 8 \\
\hline Age $(y r)$ & $35 \pm 4$ & $36 \pm 2$ & $34 \pm 5$ & $31 \pm 4$ & $32 \pm 5$ \\
\hline Duration of diabetes $(y r)$ & $20 \pm 4$ & $22 \pm 3$ & $19 \pm 4$ & - & - \\
\hline Blood pressure $(\mathrm{mmHg})$ & $166 \pm 3 / 97 \pm 2 *$ & $148 \pm 3 / 87 \pm 1$ & $150 \pm 5 / 88 \pm 6$ & $128 \pm 2 / 84 \pm 3$ & $121 \pm 4 / 82 \pm 3$ \\
\hline Blood $\mathrm{pH}(\mathrm{pH}$ units $)$ & $7.32 \pm 0.04$ & $7.38 \pm 0.02$ & $7.36 \pm 0.03$ & $7.40 \pm 0.02$ & $7.40 \pm 0.02$ \\
\hline Plasma glucose $(m g / d l)$ & $133.4 \pm 9.0^{\ddagger 5 \|}$ & $95.4 \pm 7.2$ & $118.8 \pm 3.6^{\ddagger 5 \|}$ & $86.4 \pm 1.4$ & $89.3 \pm 2.1$ \\
\hline Insulin dose $(U / d)$ & $44 \pm 3$ & - & $48 \pm 4$ & - & - \\
\hline $\mathrm{HbAlC}(\%)$ & $9.2 \pm 0.3^{ \pm \$ ॥}$ & $5.9 \pm 0.2$ & $8.7 \pm 0.4^{\ddagger \S ॥}$ & $5.6 \pm 0.2$ & $5.2 \pm 0.1$ \\
\hline Plasma urea $(m g / d l)$ & $86.8 \pm 23.5^{\ddagger}$ & $21.5 \pm 0.5$ & $34.7 \pm 0.3$ & $24.3 \pm 2.5$ & $15.6 \pm 0.2$ \\
\hline Plasma creatinine $(m g / d l)$ & $10.2 \pm 1.1^{\ddagger}$ & $1.1 \pm 0.2$ & $1.3 \pm 0.1$ & $1.1 \pm 0.1$ & $0.8 \pm 0.2$ \\
\hline Nitrogen excretion $(\mathrm{mg} / \mathrm{min})$ & $11.5 \pm 0.8^{*}$ & $7.0 \pm 0.2$ & $8.4 \pm 0.7$ & $8.0 \pm 0.3$ & $8.1 \pm 0.5$ \\
\hline Plasma free-insulin $(\mu U / m l)$ & $17.8 \pm 2.8^{\ddagger \| 1}$ & $14.8 \pm 1.6^{ \pm \| 11}$ & $6.2 \pm 1.8$ & $9.1 \pm 1.0$ & $6.8 \pm 1.1$ \\
\hline Plasma C-peptide $(\mathrm{ng} / \mathrm{ml})$ & $0.06 \pm 0.01^{\text {†\$॥ }}$ & $2.89 \pm 0.32^{*}$ & $0.05 \pm 0.02^{\ddagger \xi \|}$ & $2.51 \pm 0.14^{*}$ & $1.70 \pm 0.20$ \\
\hline Plasma growth hormone $(\mathrm{ng} / \mathrm{ml})$ & $8.93 \pm 2.12^{\ddagger \S \mid 1}$ & $2.02 \pm 0.30^{*}$ & $1.35 \pm 0.16^{*}$ & $0.47 \pm 0.14$ & $0.51 \pm 0.07$ \\
\hline Plasma glucagon $(\mathrm{pg} / \mathrm{ml})$ & $152 \pm 24^{*}$ & $127 \pm 19$ & $162 \pm 7^{*}$ & $120 \pm 14$ & $68 \pm 7$ \\
\hline Plasma cortisol $(n g / m l)$ & $154 \pm 17^{\ddagger \xi \xi \mid}$ & $65 \pm 14$ & $52 \pm 2$ & $28 \pm 4^{*}$ & $71 \pm 7$ \\
\hline Prednisone dose $(m g / d)$ & - & $10 \pm 2$ & $10 \pm 1$ & $15 \pm 3$ & - \\
\hline Cyclosporine dose $(m g / k g$ per $d)$ & - & $5 \pm 1$ & $6 \pm 1$ & $5 \pm 2$ & - \\
\hline Azathioprine dose ( $m g / k g$ per $d)$ & - & $1.0 \pm 0.2$ & $1.1 \pm 0.1$ & $1.1 \pm 0.1$ & - \\
\hline
\end{tabular}

Conversion factors to SI units: glucose $=0.05551$, urea $=0.357$, creatinine $=88.4$, free-insulin $=6.0$, C-peptide $=0.331$, growth hormone $=1.0$, glucagon $=1.0$, cortisol $=2.759$.

${ }^{*} P<0.05$ vs. $\mathrm{CON} ;{ }^{\ddagger} P<0.01$ vs. $\mathrm{CON} ;{ }^{\S} P<0.01$ vs. $\mathrm{KP}-\mathrm{Tx} ;{ }^{\|} P<0.01$ vs. $\mathrm{CU} ;{ }^{1} P<0.01$ vs. K-Tx.

\section{Methods}

\section{Subjects and experimental protocol}

9 insulin-dependent diabetic-uremic patients (IDDUP ${ }^{1}$; body mass in$\operatorname{dex}$ [BMI] 22.1 \pm 2.0 ; five males, four females), 14 patients after combined kidney-pancreas transplantation (KP-Tx; BMI 22.1 2 2.4; eight males, six females), 6 insulin-dependent diabetic patients after isolated kidney transplant (K-Tx; BMI 22.3 \pm 2.1 ; three males, three females), 5 patients with chronic uveitis $(\mathrm{CU})$ on the same immunosuppressive therapy as transplanted patients (BMI 23.0 \pm 2.2 ; three males, two females), and 8 normal healthy controls (CON; BMI 23.8 \pm 2.9 ; five males, three females) were studied. All transplants were from cadaveric donors. 8 patients received a segmental and 6 patients received a total pancreas transplant. The patients were admitted to the Metabolic Unit of San Raffaele Hospital at 8:00 a.m., at least $24 \mathrm{~h}$ before the study. All subjects underwent a 180-min euglycemic hyperinsulinemic (40 $\mathrm{mU} \cdot \mathrm{m}^{-2} \cdot \mathrm{min}^{-1}$ ) clamp, combined with indirect calorimetry as previously described (13). All IDDUP, 9 patients after KP-Tx, and all K-Tx, $\mathrm{CU}$, and $\mathrm{CON}$ subjects underwent a $\left[1-{ }^{14} \mathrm{C}\right]$ leucine infusion to assess whole-body leucine turnover and oxidation. In the remaining KP-Tx patients (5) a euglycemic insulin clamp without tracer infusion was performed. Therefore, only data on cold substrate concentration are available for those subjects. All the subjects followed an isocaloric diet containing at least $250 \mathrm{~g}$ of carbohydrates and $70-90 \mathrm{~g}$ of proteins per day in the $2 \mathrm{wk}$ preceding the study. The day before the study the fat-free mass was assessed in all subjects by means of whole-body bio-

1. Abbreviations used in this paper: BCAA, branched chain amino acids; BMI, body mass index; CON, normal subjects; $\mathrm{CU}$, chronic uveitis (patients); ELF, endogenous leucine flux; IDDUP, insulin-dependent diabetic uremic patients; K-Tx, kidney-transplanted (patients); similarly, KP-Tx, kidney/pancreas-transplanted (patients); $\alpha$ KIC, $\alpha$-ketoisocaproic acid; LO, leucine oxidation; NLB, net leucine balance; NOLD, nonoxidative leucine disposal. electrical impedance as previously described $(16,17)$. In IDDUP the fat-free mass was assessed at the end of the hemodialytic session (17). IDDUP were dialyzing $3 \mathrm{~d} / \mathrm{wk}$; the study was usually done within $48 \mathrm{~h}$ from the last hemodialytic session. All subjects were fully informed of the possible risks of the study and gave their consent. The experimental protocol was approved by the Institutional Ethical Committee. Table I summarizes the clinical and laboratory data of the five study groups. All values in the table refer to blood samples drawn the morning of study 1 .

After an overnight fast, at 6:00 a.m. a polyethylene catheter ( $18 \mathrm{G}$, Terumo, Leuven, Belgium) was inserted into an antecubital vein for the infusion of all test substances. A second catheter was inserted retrogradely into a wrist vein and advanced to the dorsum of the hand for blood sampling. The hand was placed in an heated box $\left(70^{\circ} \mathrm{C}\right)$ to ensure arterialization of the venous blood (18). A prime-continuous infusion of $\left[1-{ }^{14} \mathrm{C}\right]$ leucine was administered $(16 \mu \mathrm{Ci}$ as a bolus injection, followed by $0.20 \mu \mathrm{Ci} / \mathrm{min}$ as a continuous infusion; Amersham Corp., Arlington Heights, IL; aqueous solution containing $2 \%$ ethanol), in combination with a priming dose of $\mathrm{NaH}^{14} \mathrm{CO}_{3}(2.3 \mu \mathrm{Ci}$, Amersham, sodium salt) to prime the body bicarbonate pool $(4,19)$. After $2 \mathrm{~h}$ of isotope equilibration, samples were drawn at 10-min intervals from 120 to $180 \mathrm{~min}$ for the determination of basal leucine and $\alpha$-ketoisocaproic acid ( $\alpha$-KIC) specific activities, as well as hormone and substrate concentrations.

Continuous indirect calorimetry was started 90 min after the tracer infusion was initiated, and continued throughout the study. Expired air samples were collected at 15 -min intervals and bubbled through a $\mathrm{CO}_{2}$ trapping solution (hyamine hydroxide/absolute ethanol $/ 0.1 \%$ phenolphthalein, 3:5:1) as described previously $(4,19)$. The solution was titrated to trap $1 \mathrm{mmol} \mathrm{CO}_{2}$ per $3 \mathrm{ml}$ of solution. The ${ }^{14} \mathrm{C}$ radioactivity was subsequently determined with a $\beta$ scintillation counter (Packard Instrument $\mathrm{Co}$. Inc., Meriden, $\mathrm{CT}$ ) and the expired ${ }^{14} \mathrm{CO}_{2}$ specific activity was calculated. Total ${ }^{14} \mathrm{CO}_{2}$ expired per minute was determined by multiplying the ${ }^{14} \mathrm{CO}_{2}$ specific activity by the total $\mathrm{CO}_{2}$ production, determined as described below. The experimental protocol is depicted in Fig. 1. 
Study 1: insulin clamp. All the subjects participated in this study protocol. After a 180-min equilibration period an insulin clamp was performed as previously described (13). Briefly a prime-continuous infusion of crystalline human insulin (Actrapid HM, Novo Nordisk, Copenhagen, Denmark) was administered at the rate of 40 $\mathrm{mU} \cdot \mathrm{m}^{-2} \cdot \mathrm{min}^{-1}$ to achieve and maintain an increment in plasma insulin concentration of $\sim 75 \mu \mathrm{U} / \mathrm{ml}$. The plasma glucose concentration was maintained at the basal level by measuring it at 5-min intervals and by periodic adjustment of a $20 \%$ glucose infusion based on a negative feedback principle.

Study 2: insulin clamp with amino acid infusion. Six IDDUP, seven KP-Tx patients, four K-Tx patients, four CU patients, and five CON were studied with a repeat insulin clamp. The insulin clamp was performed as described above with one exception. A balanced amino acid solution was begun at the start of the insulin infusion and continued throughout the study as previously described (4). The rate of amino acid infusion averaged $0.98 \pm 0.11 \mathrm{ml} \cdot \mathrm{m}^{-2} \cdot \mathrm{min}^{-1}$ (cold leucine infusion rate of $\left.51 \pm 6 \mu \mathrm{mol} \cdot \mathrm{m}^{-2} \cdot \mathrm{min}^{-1}\right)$ in all study groups. These infusion rates were chosen to simulate the postprandial plasma amino acid
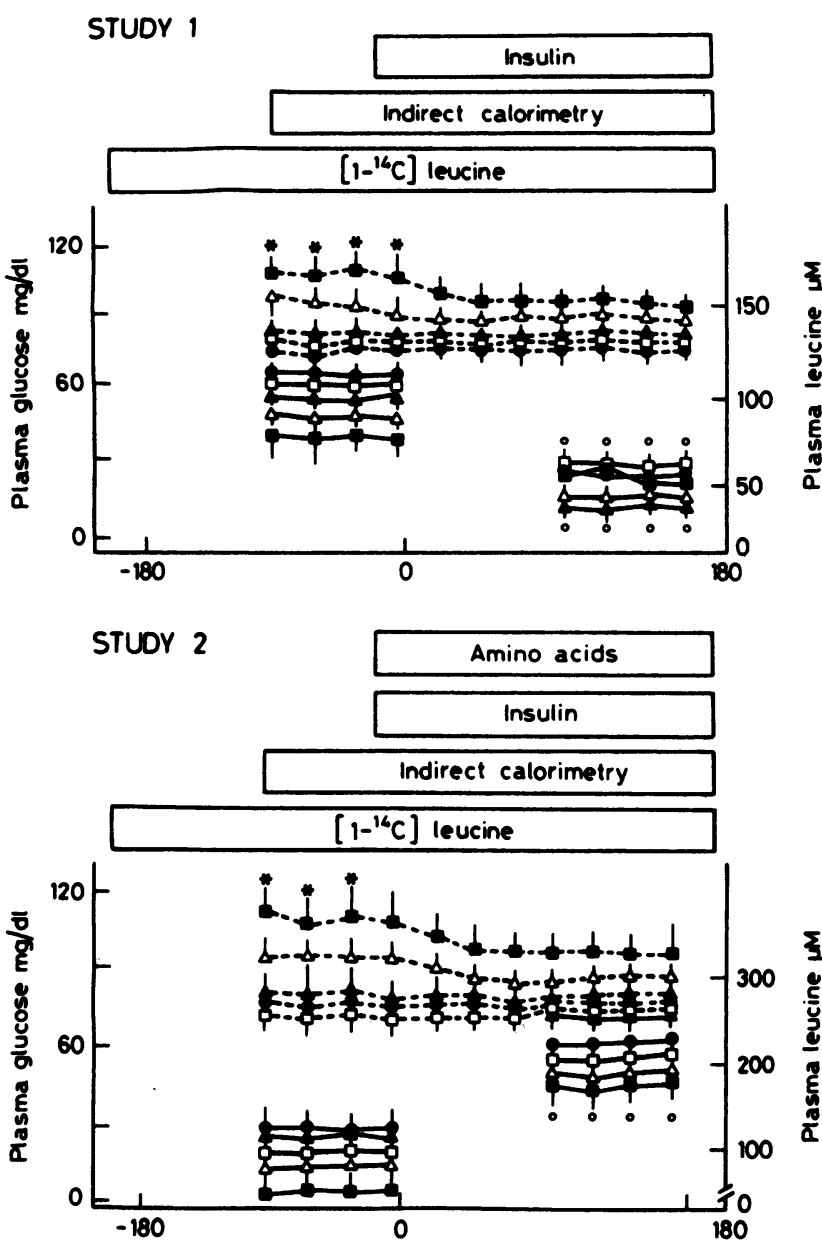

Figure 1. Experimental protocols of both Studies 1 and 2. [1- $\left.{ }^{14} \mathrm{C}\right]-$ Leucine infusion and indirect calorimetry were performed in both studies. During study 1 , after $180 \mathrm{~min}$ of basal equilibration, a 40 $\mathrm{mU} \cdot \mathrm{m}^{-2} \cdot \mathrm{min}^{-1}$ insulin infusion was started and continued for 180 min. Study 2 was similar to study 1 with one exception. A balanced amino acid solution was infused along with insulin in order to double the plasma amino acid concentration. Solid lines refer to plasma leucine; dashed lines refer to plasma glucose level. ( $\bullet$ ) IDDUP; $(\Delta) \mathrm{KP}$ -

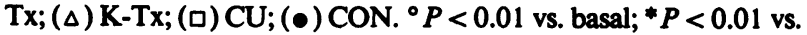
groups 2,4 , and 5 . concentrations. The aim was to obtain the same increment with respect to the basal levels in all groups.

Respiratory exchange measurements. In all studies, total $\mathrm{CO}_{2}$ production rate and $\mathrm{O}_{2}$ consumption rate were measured by continuous indirect calorimetry as reported previously (13), by means of SensorMedics instrumentation, Model Horizon, Anaheim, CA. Nonprotein respiratory quotient was measured using the Lusk's table as reviewed and discussed by Simonson and DeFronzo (20). Nitrogen excretion rate in the IDDUP was quantified as previously described (13).

\section{Analytical determinations and calculations}

Plasma leucine concentration and specific activity were determined using an HPLC system (System Gold, Beckman Instruments, Inc., Palo Alto, CA) constituted by a programmable solvent module (model $126 \mathrm{AA}$ ) and a programmable detector module, model 168 as previously described (4). Briefly, to precipitate plasma proteins $50 \mathrm{mg}$ of sulfosalycilic acid (dry powder) was added to $1.0 \mathrm{ml}$ of plasma and a $100-\mu l$ aliquot of the supernatant was analyzed in duplicate for amino acid concentration. $1 \mathrm{ml}$ of the remaining supernatant was placed in duplicate on a cation exchange resin column (Dowex $50 \mathrm{G}$, Bio-Rad Laboratories, Richmond, CA) and the free amino acid fraction was eluted with $4 \mathrm{~N} \mathrm{NH}_{4} \mathrm{OH}$, dehydrated, and reconstituted in water. $10 \mathrm{ml}$ of Picofluor 15 scintillation fluid (Packard) was added to each vial and ${ }^{14} \mathrm{C}$ radioactivity was measured in a scintillation counter. The recovery of $\left[1-{ }^{14} \mathrm{C}\right]$ leucine added to plasma was $98 \pm 2 \%$. The interassay and intraassay variations for the determination of $\left[1-{ }^{14} \mathrm{C}\right]$ leucine specific activity were $3 \pm 1 \%$ and $4 \pm 2 \%$, respectively. $>98 \%$ of the radioactivity collected in the amino acid fraction was in the leucine peak after separation by ion exchange chromatography (21). Plasma $\alpha$-KIC specific activity was measured as previously described $(4,22)$. Briefly, $1 \mathrm{ml}$ of plasma was placed in duplicate on a Dowex $50 \mathrm{G}$ cation exchange resin column (Bio-Rad Laboratories) and the free $\alpha$-ketoacid fraction was eluted with $4 \mathrm{ml}$ of $0.01 \mathrm{~N} \mathrm{HCl}$ in $50 \mathrm{ml}$ cell culture tubes. $35 \mathrm{ml}$ of methylene chloride was added and after shaking vigorously for $1 \mathrm{~min}$ the tubes were centrifuged for $5 \mathrm{~min}$ at $2,000 \mathrm{rpm}$ to extract the free $\alpha$-ketoacid fraction from the plasma. After decanting the supernatant the $\alpha$-ketoacids were extracted in $350 \mu \mathrm{l}$ of $0.2 \mathrm{M} \mathrm{NaH}_{3} \mathrm{PO}_{3}$ at $\mathrm{pH}$ 7.0. After a brief centrifugation $200 \mu \mathrm{l}$ of the resultant supernatant was injected into an HPLC system. The system utilized a $C_{18}$ reverse-phase column (Altex-Ultrasphere ODS, $0.6 \times 25 \mathrm{~cm}$; Beckman, Instruments, Inc., Palo Alto, CA) that was eluted with $5 \%$ acetonitrile in $0.2 \mathrm{M}$ $\mathrm{H}_{3} \mathrm{PO}_{4}$ buffer ( $\mathrm{pH} \mathrm{7.4)} \mathrm{at} \mathrm{the} \mathrm{rate} \mathrm{of} 1.4 \mathrm{ml} / \mathrm{min}$. Absorbance of $\alpha-\mathrm{KIC}$ was monitored at $206 \mathrm{~nm}$. Radioactivity eluting with the $\alpha$-KIC peak was measured by liquid scintillation $\beta$-counting (4). All calculations were made during the last hour of the tracer equilibration and of the insulin clamp period when steady-state conditions for leucine and $\alpha$ KIC specific activities and concentrations existed. Data were analyzed using a stochastic model as previously described $(4,23)$. The model generates the following equations in which the total leucine turnover or flux equals: $Q=S+C=B+\mathrm{I}$, where $S$ is the rate of leucine incorporation into protein (nonoxidative leucine disposal); $C$ is the rate of leucine oxidation; $B$ is the rate of leucine release from protein (endogenous leucine appearance); and $I$ is the rate of exogenous leucine input. The rate of leucine turnover $(Q)$ is calculated as follows: $Q=F /$ leucine specific activity, where $F$ is the infusion rate of $\left[1-{ }^{14} \mathrm{C}\right]$ leucine (in dpm/ $\mathrm{min}$ ) and leu specific activity is the specific radioactivity of leucine in the plasma compartment under conditions of equilibrium. The leucine oxidation rate $(C)$ is calculated as follows: $C=O /(K \cdot$ leucine specific activity), where $O$ is the rate of appearance of ${ }^{14} \mathrm{CO}_{2}$ in the expired air (in $\mathrm{dpm} / \mathrm{min}$ ) and $K$ is a correction factor $(0.81)$ which takes into account the incomplete recovery of labeled ${ }^{14} \mathrm{CO}_{2}$ from the bicarbonate pool. In particular, the 0.81 factor accounts for the fraction of ${ }^{14} \mathrm{CO}_{2}$ released into the body's bicarbonate pool from the oxidation of $\left[1-{ }^{14} \mathrm{C}\right]-$ leucine, but not recovered in expired air $(24,25)$. An estimate of the rate of leucine incorporation into protein $(S)$ can be calculated as follows: $S=Q-C$. An estimate of the rate of leucine release into plasma space from endogenous protein $(B)$ can be calculated as follows: $B=Q-I$ 
When the subjects are in the postabsorptive state, the leucine intake ( $I$ ) equals $O$ and $B=Q$. When amino acids are being infused intravenously, the rate of exogenous leucine infusion $(I)$ must be subtracted from the total leucine flux $(Q)$ in order to calculate the rate of endogenous leucine release from proteins. To calculate the rates of leucine turnover and oxidation, we used the plasma leucine specific activity. Recent publications have suggested that the plasma specific activity of the transaminated product of leucine, the $\alpha-\mathrm{KIC}$, may provide a better indicator of the specific activity in the intracellular mixing pool (26, 27). Therefore, estimates of leucine kinetics were also carried out using the plasma $\alpha$-KIC specific activity.

Plasma glucose concentrations were determined by a differentialpH method previously described (28). Methods for determining plasma free insulin (13), glucagon (13), cortisol (13), growth hormone (13), and epinephrine (29) concentrations have been previously described. Nitrogen excretion rate was assessed as previously described (13).

\section{Statistical analysis}

All values are expressed as the mean $\pm \mathrm{SE}$. Comparisons between the basal and the insulin-stimulated states within a group were performed with the Student's $t$ test for paired data. Comparisons among the various groups were performed with the ANOVA and the Student's $t$ test (30).

\section{Results}

Plasma glucose, hemoglobin ( $\mathrm{Hb}$ ) $A_{l c}$, hormone concentrations, and nitrogen excretion rate (Tables I-III). In the basal state, plasma glucose concentration was higher in IDDUP and $\mathrm{K}-\mathrm{Tx}$ respect to $\mathrm{KP}-\mathrm{Tx}, \mathrm{CU}$, and $\mathrm{CON}(P<0.01)$. In contrast, during the last hour of studies 1 and 2, it did not differ significantly among the various study groups (Tables I and III and Fig. 1). $\mathrm{HbA}_{1 \mathrm{c}}$ concentration was increased in IDDUP and $\mathrm{K}-\mathrm{Tx}$ with respect to the other groups ( Table I). Postabsorptive free-IRI concentration was increased in the basal state in IDDUP and KP-Tx with respect to CU and CON $(P<0.01)$. During studies 1 and 2 the increment of free-insulin was similar in the five groups (Table II, Fig. 1). Basal glucagon concentration was higher in IDDUP and K-Tx with respect to KP-Tx, $\mathrm{CU}$, and $\mathrm{CON}(P<0.05)$ (Table I). During both studies 1 and 2 , plasma glucagon concentration did not change significantly from the basal state, in any of the groups (Table II). Basal growth hormone concentration was increased $(P<0.01)$ in IDDUP $(8.93 \pm 2.12)$ vs. KP-Tx $(2.02 \pm 0.30), \mathrm{K}-\mathrm{Tx}(1.35 \pm 0.16)$,

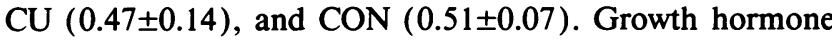
concentration increased significantly with respect to basal in KP-Tx and K-Tx $(P<0.05)$ during euglycemic hyperinsulinemia (Table II). Cortisol concentration was higher in IDDUP vs. all groups $(P<0.01)$ (Table II). Plasma epinephrine concentration was increased in the basal state in IDDUP $(1,961 \pm 320 \mathrm{pM})$ vs. all groups $(P<0.01)$ (Table II).

In the basal state, plasma FFA were similar in IDDUP $(0.589 \pm 0.08), \mathrm{KP}-\mathrm{Tx}(0.521 \pm 0.06), \mathrm{K}-\mathrm{Tx}(0.681 \pm 0.04), \mathrm{CU}$ $(0.610 \pm 0.01)$, and CON $(0.592 \pm 0.01 \mathrm{mM})$ (Table III). During euglycemic hyperinsulinemia the FFA concentration decreased of a similar value in IDDUP $(0.398 \pm 0.01)$ respect to KP-Tx $(0.358 \pm 0.01), \mathrm{K}-\mathrm{Tx}(0.524 \pm 0.02), \mathrm{CU}(0.457 \pm 0.1)$, and $\mathrm{CON}(0.449 \pm 0.2 \mathrm{mM})$.

The nitrogen excretion rate was increased in IDDUP with respect to KP-Tx, K-Tx, CU, and CON $(P<0.01)$.

Fat-free mass. In IDDUP $(\mathrm{BW}=62.1 \pm 3.2 \mathrm{~kg})$ the fat-free mass $(73.7 \pm 2.9 \%)$ was slightly reduced compared to KP-Tx $(77.2 \pm 2.1 \%), \mathrm{K}-\mathrm{Tx}(74.2 \pm 1.8 \%), \mathrm{CU}(74.4 \pm 2.1 \%)$, and CON
(75.4 $\pm 2.3 \%)$. However, no statistically significant difference was detected among any of the groups.

Plasma amino acid, leucine, and $\alpha$-KIC concentrations and specific activities in the postabsorptive state in the five study groups (Table III, Fig. 1). In IDDUP, the fasting branched chain amino acid (BCAA) $(297 \pm 34 \mu \mathrm{M})$, and leucine concentrations $(92 \pm 9 \mu \mathrm{M})$ were all lower $(P<0.05)$ than those in control subjects (CON: $416 \pm 10$ and $124 \pm 2 \mu \mathrm{M}$ for BCAA and leucine, respectively) (Table II). The fasting $\alpha$-KIC concentration $(19 \pm 3$ vs. $28 \pm 2 \mu \mathrm{M})$ was also lower $(P<0.05)$ with respect to CON. After KP-Tx and in insulin-dependent diabetic patients after isolated $\mathrm{K}-\mathrm{Tx}$, the basal plasma BCAA $(340 \pm 14$, and $311 \pm 11 \mu \mathrm{M}$, respectively) increased with respect to IDDUP, still being significantly lower than normals $(P<0.05)$. Basal BCAA in CU $(459 \pm 32 \mu \mathrm{M})$ was similar to those in CON $(416 \pm 10 \mu \mathrm{M})$. Basal plasma leucine $(116 \pm 5,107 \pm 9$, and $121 \pm 8 \mu \mathrm{M})$, and basal plasma $\alpha$-KIC $(23 \pm 1,24 \pm 2$, and $35 \pm 4$ $\mu \mathrm{M}$ ) in KP-Tx, K-Tx, and CU, respectively, did not differ from those in CON (Table II). Basal plasma leucine, $(3.61 \pm 0.52$ $\mathrm{dpm} / \mathrm{nmol})$ and $\alpha-\mathrm{KIC}(2.44 \pm 0.71 \mathrm{dpm} / \mathrm{nmol})$ specific activities in IDDUP were significantly higher compared with those of CON ( $1.94 \pm 0.21$ and $1.27 \pm 0.10 \mathrm{dpm} / \mathrm{nmol}$, respectively; $P$ $<0.05$ ), as well as in $\mathrm{KP}-\mathrm{Tx}, \mathrm{K}-\mathrm{Tx}$, and $\mathrm{CU}$, respectively (plasma leucine $[2.93 \pm 0.24,2.63 \pm 0.48$, and $2.91 \pm 0.03 \mathrm{dpm} /$ $\mathrm{nmol}]$ and $\alpha$-KIC $[1.97 \pm 0.11,1.77 \pm 0.22$, and $1.79 \pm 0.08$ $\mathrm{dpm} / \mathrm{nmol}]$ ). Plasma phenylalanine concentration was not statistically different among the five study groups (Table III). Plasma alanine concentration was higher in IDDUP and CU vs. Groups KP-Tx, K-Tx, and CON subjects $(P<0.05)$. A steady-state plasma plateau was achieved for the leucine and $\alpha$-KIC specific activities during the last hour of the equilibration period in all study groups.

Plasma amino acid, leucine, and $\alpha-K I C$ concentration and specific activities during study 1 (hyperinsulinemia) and study 2 (combined hyperinsulinemia/hyperaminoacidemia) (Table III, Fig. 1). During study 1, IDDUP demonstrated a decrease in all measured plasma amino acid concentrations with the notable exception of alanine. The BCAA concentration decreased from $297 \pm 34$ to $182 \pm 25$, from $340 \pm 14$ to $151 \pm 9$, from $311 \pm 11$ to $133 \pm 24$, from $459 \pm 32$ to $264 \pm 28$, and from $416 \pm 10$ to $221 \pm 13 \mu \mathrm{M}$ in IDDUP, KP-Tx, K-Tx, CU, and CON, respectively. Plasma leucine concentration decreased from $92 \pm 9$ to $53 \pm 6$, from $116 \pm 5$ to $42 \pm 5$, from $107 \pm 9$ to $43 \pm 4$, from $121 \pm 8$ to $59 \pm 4$, and from $124 \pm 2$ to $58 \pm 2 \mu \mathrm{M}$ in IDDUP, KP-Tx, K-Tx, CU, and CON, respectively. Plasma $\alpha$-KIC concentration decreased from $19 \pm 3$ to $12 \pm 2$, from $23 \pm 1$ to $14 \pm 1$, from $24 \pm 2$ to $12 \pm 1$, from $35 \pm 4$ to $19 \pm 2$, and from $28 \pm 2$ to $14 \pm 2 \mu \mathrm{M}$ in IDDUP, KP-Tx, K-Tx, CU, and $\mathrm{CON}$, respectively. The absolute decrease of plasma leucine concentration from baseline ( $39 \pm 6$ vs. $66 \pm 4 \mu \mathrm{M})$ was significantly less $(P<0.01)$ in IDDUP compared to CON (Table III). In the patients studied after KP-Tx, the absolute decreases in BCAA $(189 \pm 36$ vs. $195 \pm 20 \mu \mathrm{M})$, leucine ( $74 \pm 11$ vs. $66 \pm 4$ $\mu \mathrm{M})$, and $\alpha$-KIC $(9 \pm 1$ vs. $14 \pm 2 \mu \mathrm{M})$ concentrations were nearly identical to those observed in CON (Fig. 1, Table III). A steady-state plateau of plasma leucine and $\alpha$-KIC concentrations and specific activities was achieved in all study subjects during the last hour of insulin infusion.

The plasma BCAA $(487 \pm 58,640 \pm 84,598 \pm 92,602 \pm 87$, and $683 \pm 69 \mu \mathrm{M})$, leucine $(157 \pm 22,220 \pm 8,207 \pm 23,209 \pm 17$, and $215 \pm 5 \mu \mathrm{M})$, and $\alpha$-KIC $(23 \pm 2,23 \pm 1,29 \pm 2,30 \pm 3$, and $27 \pm 3 \mu \mathrm{M}$ ) concentrations were similar in IDDUP, KP-Tx, K- 

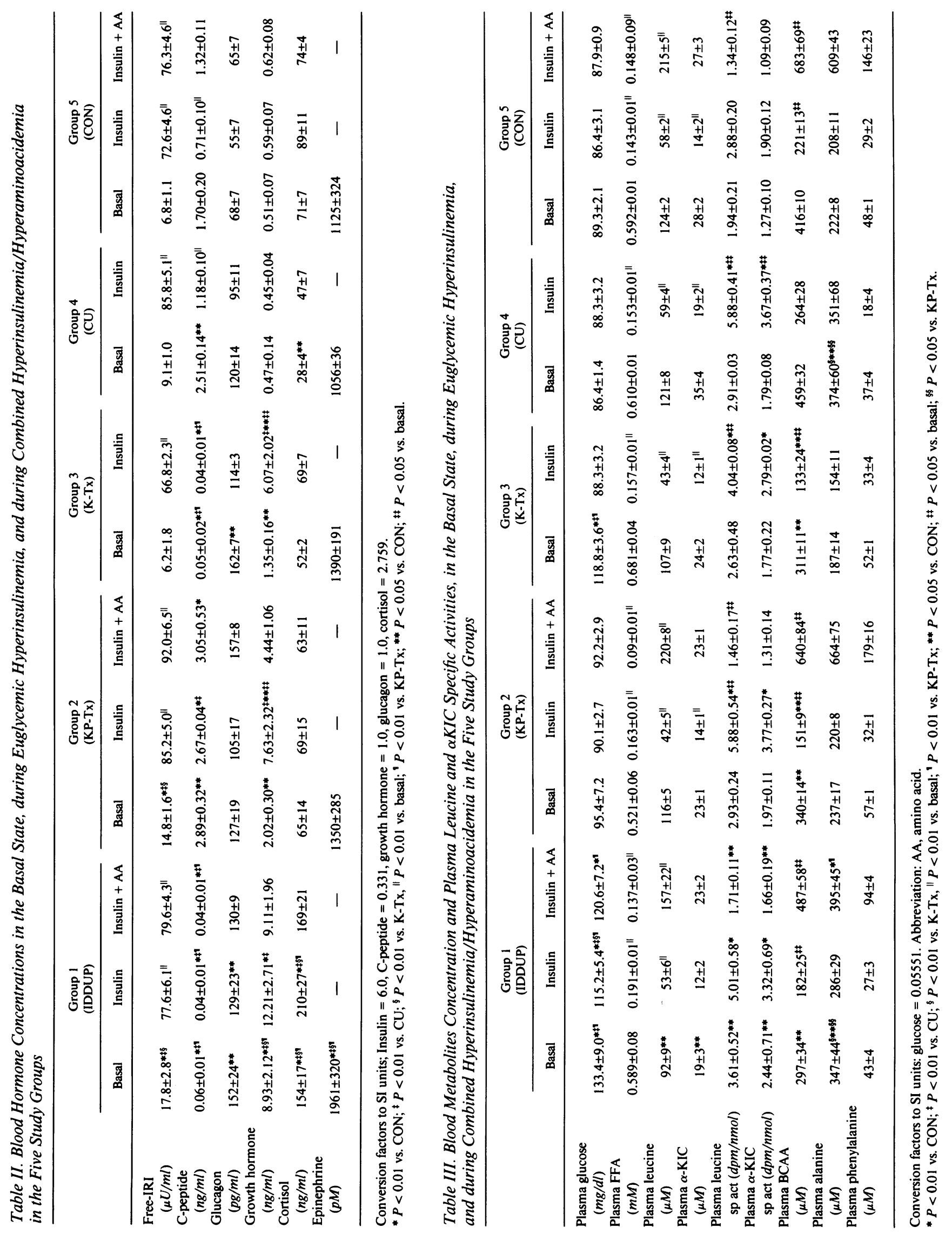
Tx, CU, and CON during the last hour of study 2 . The plasma leucine and $\alpha$-KIC specific activities, respectively, were significantly higher $(P<0.05)$ in IDDUP $(1.71 \pm 0.11$ and $1.66 \pm 0.19$ $\mathrm{dpm} / \mathrm{nmol})$ with respect to KP-Tx $(1.46 \pm 0.17$ and $1.31 \pm 0.14$ $\mathrm{dpm} / \mathrm{nmol}), \mathrm{K}-\mathrm{Tx}(1.33 \pm 0.31$ and $0.96 \pm 0.11 \mathrm{dpm} / \mathrm{nmol})$, CU $(1.34 \pm 0.28$ and $0.88 \pm 0.23 \mathrm{dpm} / \mathrm{nmol})$, and CON $(1.34 \pm 0.12$ and $1.09 \pm 0.09 \mathrm{dpm} / \mathrm{nmol})$.

Total leucine flux. In the postabsorptive state, total leucine flux averaged $28.7 \pm 0.8 \mu \mathrm{mol} \cdot \mathrm{m}^{-2} \cdot \mathrm{min}^{-1}$ in IDDUP, a significantly lower value $(P<0.01)$ compared to KP-Tx $(38.1 \pm 0.1)$, $\mathrm{K}-\mathrm{Tx}(38.5 \pm 0.9), \mathrm{CU}(38.0 \pm 0.4)$, and CON (39.5 \pm 0.7 $\left.\mu \mathrm{mol} \cdot \mathrm{m}^{-2} \cdot \mathrm{min}^{-1}\right)$.

During study 1 total leucine flux decreased less $(P<0.01)$ in IDDUP (from $28.7 \pm 0.8$ to $20.6 \pm 0.7$ ) compared to KP-Tx, $\mathrm{K}-\mathrm{Tx}, \mathrm{CU}$, and CON (from $38.1 \pm 0.1$ to $18.9 \pm 0.4,38.5 \pm 0.9$ to $25.1 \pm 0.7,38.0 \pm 0.4$ to $18.8 \pm 0.5$, and $39.5 \pm 0.7$ to $26.6 \pm 0.3$ $\mu \mathrm{mol} \cdot \mathrm{m}^{-2} \cdot \mathrm{min}^{-1}$, respectively). During study 2 , IDDUP showed a $56 \%$ increase of total leucine flux $(28.7 \pm 0.8$ to $\left.44.9 \pm 3.1 \mu \mathrm{mol} \cdot \mathrm{m}^{-2} \cdot \mathrm{min}^{-1}\right)$. This increase was similar to that in KP-Tx (from $42.8 \pm 1.7$ to $84.4 \pm 2.6$ ), $\mathrm{K}-\mathrm{Tx}$ (from $37.8 \pm 1.1$ to $75.7 \pm 8.2), \mathrm{CU}(37.9 \pm 0.5$ to $78.5 \pm 7.9)$, and $\mathrm{CON}$ $\left(41.5 \pm 0.6\right.$ to $\left.69.4 \pm 3.1 \mu \mathrm{mol} \cdot \mathrm{m}^{-2} \cdot \mathrm{min}^{-1}\right)$.

Endogenous leucine flux (ELF) (protein catabolism) ( $\mathrm{Ta}$ ble IV). The endogenous leucine flux (which provides a measure of protein degradation) is equal to the total leucine flux in the basal state as well as in the studies performed without amino acid infusion.

In study 2, the combination of hyperinsulinemia and hyperaminoacidemia caused a similar absolute decline of ELF in IDDUP $\left(28.7 \pm 0.8\right.$ to $\left.4.8 \pm 0.5 \mu \mathrm{mol} \cdot \mathrm{m}^{-2} \cdot \mathrm{min}^{-1}\right)$, KP-Tx (42.8 \pm 1.7 to $20.5 \pm 0.5)$, K-Tx (37.81.1 to 19.90.9), CU (37.90.5 to 22.31 .1$)$, and CON $(41.5 \pm 0.6$ to $18.9 \pm 0.9$ $\left.\mu \mathrm{mol} \cdot \mathrm{m}^{-2} \cdot \min ^{-1}\right)$.

Leucine oxidation ( $L O$ ) (Table IV). In the postabsorptive state, leucine oxidation was similar in IDDUP $(8.0 \pm 0.1$ $\left.\mu \mathrm{mol} \cdot \mathrm{m}^{-2} \cdot \min ^{-1}\right), \mathrm{KP}-\mathrm{Tx}(9.8 \pm 0.3), \mathrm{K}-\mathrm{Tx}(7.5 \pm 0.3), \mathrm{CU}$ $(6.6 \pm 0.4)$, and CON $\left(7.5 \pm 0.1 \mu \mathrm{mol} \cdot \mathrm{m}^{-2} \cdot \mathrm{min}^{-1}\right)$. During study 1 both IDDUP (from $8.0 \pm 0.1$ to $8.5 \pm 0.3 \mu \mathrm{mol} \cdot \mathrm{m}^{-2}$. $\mathrm{min}^{-1}$ ) and K-Tx (from $7.5 \pm 0.3$ to $6.1 \pm 0.4 \mu \mathrm{mol} \cdot \mathrm{m}^{-2}$. $\mathrm{min}^{-1}$ ) demonstrated a defective suppression of leucine oxidation when compared to KP-Tx (from $9.8 \pm 0.3$ to $4.6 \pm 0.2$ ), CU (from $6.6 \pm 0.4$ to $3.1 \pm 0.1$ ), and CON (from $7.5 \pm 0.1$ to $\left.5.1 \pm 0.1 \mu \mathrm{mol} \cdot \mathrm{m}^{-2} \cdot \mathrm{min}^{-1}\right)$. During study 2 the leucine oxidation increased less in IDDUP (from $5.0 \pm 0.4$ to $17.0 \pm 0.5$ $\left.\mu \mathrm{mol} \cdot \mathrm{m}^{-2} \cdot \mathrm{min}^{-1}\right)$ with respect to KP-Tx $(6.0 \pm 0.8$ to $40.1 \pm 0.4), \mathrm{K}-\mathrm{Tx}(6.9 \pm 0.9$ to $35.6 \pm 1.2)$, CU $(7.0 \pm 1.1$ to $33.2 \pm 1.0)$, and $\operatorname{CON}(7.3 \pm 0.2$ to $33.3 \pm 0.2 \mu \mathrm{mol}$ $\left.\mathrm{m}^{-2} \cdot \min ^{-1}\right)$.

Nonoxidative leucine disposal (protein synthesis) (NOLD) (Table IV). In the postabsorptive state the NOLD (an index of protein synthesis) was significantly reduced in IDDUP $\left(20.7 \pm 0.2 \mu \mathrm{mol} \cdot \mathrm{m}^{-2} \cdot \mathrm{min}^{-1}\right)$ with respect to normal controls $\left(32.0 \pm 0.7 \mu \mathrm{mol} \cdot \mathrm{m}^{-2} \cdot \mathrm{min}^{-1} ; P<0.01\right)$ KP-Tx $(28.3 \pm 0.6$ $\left.\mu \mathrm{mol} \cdot \mathrm{m}^{-2} \cdot \mathrm{min}^{-1}\right), \mathrm{K}-\mathrm{Tx}\left(31.0 \pm 1.3 \mu \mathrm{mol} \cdot \mathrm{m}^{-2} \cdot \mathrm{min}^{-1}\right)$, and $\mathrm{CU}\left(31.4 \pm 0.1 \mu \mathrm{mol} \cdot \mathrm{m}^{-2} \cdot \mathrm{min}^{-1}\right)$ demonstrated no difference in NOLD with respect to normals $(P=\mathrm{NS})$. During the insulin clamp (study 1 ), NOLD decreased less in IDDUP $(20.7 \pm 0.2$ to $12.1 \pm 0.4)$ than in KP-Tx $(28.3 \pm 0.6$ to $14.3 \pm 0.3)$, K-Tx $(31.0 \pm 1.3$ to $19.0 \pm 0.9), \mathrm{CU}(31.4 \pm 0.1$ to $15.7 \pm 0.5)$, and

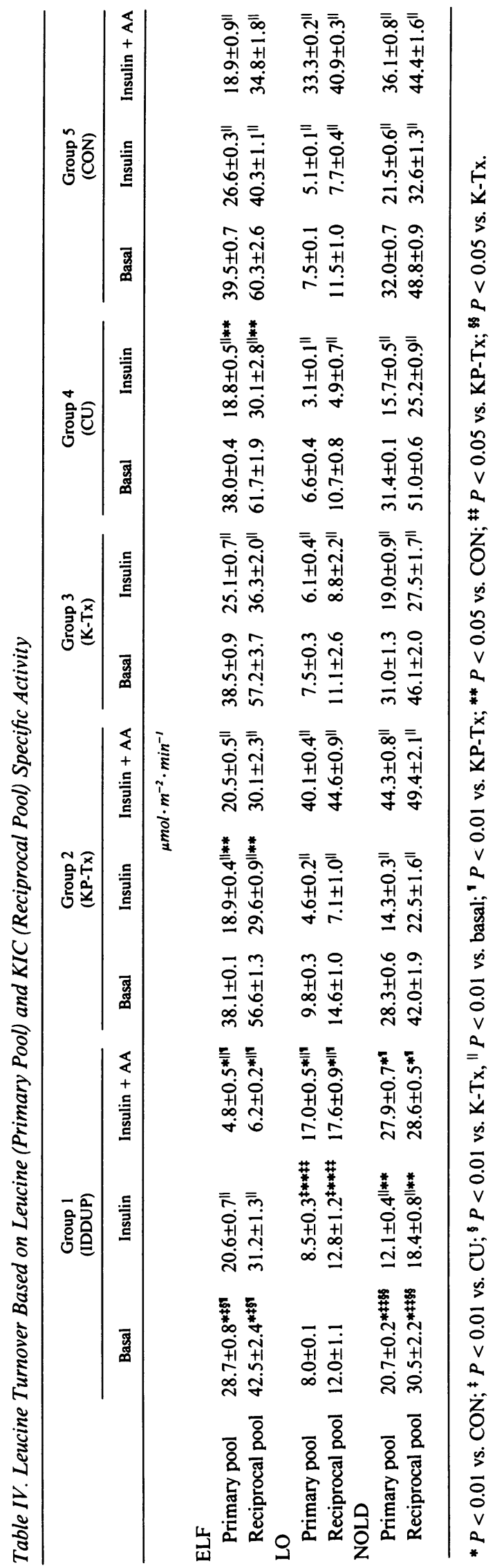


CON (32.0 \pm 0.7 to $21.5 \pm 0.6)$. During study 2, NOLD rose significantly above the basal rate in KP-Tx (from 34.1 \pm 1 .1 to $44.3 \pm 0.8), \mathrm{K}-\mathrm{Tx}(30.9 \pm 1.2$ to $40.1 \pm 2.7), \mathrm{CU}(30.5 \pm 1.9$ to $45.3 \pm 2.9$ ), and CON (from $31.2 \pm 0.8$ to $36.1 \pm 0.8$ ), while in IDDUP (from $24.1 \pm 1.1$ to $27.9 \pm 0.7 ; P=\mathrm{NS}$ ) it did not show any significant change from the basal value.

Net leucine balance. In the basal state all study groups demonstrated a similar negative flux of leucine into and out of proteins, averaging $-8.0 \pm 0.1,-9.8 \pm 0.3,-7.5 \pm 0.3,-6.6 \pm 0.4$, and $-7.5 \pm 0.1 \mu \mathrm{mol} \cdot \mathrm{m}^{-2} \cdot \mathrm{min}^{-1}$ in IDDUP, KP-Tx, K-Tx, $\mathrm{CU}$, and $\mathrm{CON}$, respectively. During study 1 , the net leucine balance did not change from the basal value in IDDUP $\left(-8.5 \pm 0.3 \mu \mathrm{mol} \cdot \mathrm{m}^{-2} \cdot \min ^{-1}\right)$, while it became less negative in KP-Tx $(-4.6 \pm 0.2), \mathrm{K}-\mathrm{Tx}(-6.1 \pm 0.4), \mathrm{CU}(-3.1 \pm 0.1)$, and CON $(-5.1 \pm 0.1)$ compared with the value in the basal state. During study 2, the combined hyperaminoacidemia/hyperinsulinemia induced a similar positive net leucine balance in IDDUP ( from $-5.0 \pm 0.4$ to $23.1 \pm 0.9 \mu \mathrm{mol} \cdot \mathrm{m}^{-2} \cdot \mathrm{min}^{-1}$ ), KP-Tx (from $-6.0 \pm 0.8$ to $23.8 \pm 1.9$ ), K-Tx $(-6.9 \pm 0.9$ to $20.2 \pm 2.0$ ), CU ( $-7.0 \pm 1.1$ to $23.0 \pm 2.1$ ), and $\mathrm{CON}$ (from $-7.3 \pm 0.4$ to $\left.17.2 \pm 1.6 \mu \mathrm{mol} \cdot \mathrm{m}^{-2} \cdot \mathrm{min}^{-1}\right)$.

Leucine turnover based on KIC specific activity (Tables IV and $V$ ). Because it has been suggested that plasma $\mathrm{KIC}$ specific activity may provide a more accurate index of the intracellular precursor pool involved in leucine turnover, all calculations were repeated utilizing the steady-state plasma KIC specific activity achieved during the last hour of the basal and experimental periods. Table IV shows that the qualitative changes in leucine turnover (LO, ELF, and NOLD) calculated with the plasma KIC specific activity (reciprocal pool model), closely parallel those determined with the plasma leucine specific activity (primary pool model) under the present experimental conditions. During combined hyperinsulinemia/hyperaminoacidemia the NOLD was defectively stimulated in IDDUP (from $30.5 \pm 2.2$ to $\left.28.6 \pm 0.5 \mu \mathrm{mol} \cdot \mathrm{m}^{-2} \cdot \mathrm{min}^{-1}\right)$, while it showed a similar stimulation in KP-Tx, K-Tx, CU, and CON (49.4 \pm 2.1 , $54.2 \pm 5.4,60.7 \pm 5.1$ and 54.4 \pm 1.6 , respectively).

Glucose metabolism. During the $120-180$ min of study 1 in IDDUP, the glucose infusion rate required to maintain euglycemia was $3.4 \pm 1.6 \mathrm{mg} \cdot \mathrm{kg}^{-1} \cdot \mathrm{min}^{-1}$, significantly less $(P$ $<0.01$ ) than the other groups. After KP-Tx and after K-Tx, the glucose infusion rate required to maintain euglycemia increased to $6.0 \pm 0.8$ and $4.2 \pm 0.9 \mathrm{mg} \cdot \mathrm{kg}^{-1} \cdot \mathrm{min}^{-1}$, respectively. CU patients' insulin-stimulated glucose metabolism was still defective with respect to $\mathrm{CON}$ (normals) (6.2 \pm 0.2 vs. $7.5 \pm 0.3$ $\mathrm{mg} \cdot \mathrm{kg}^{-1} \cdot \mathrm{min}^{-1}$ ).

During study 2 the glucose infusion rates in IDDUP, KP$\mathrm{Tx}, \mathrm{K}-\mathrm{Tx}, \mathrm{CU}$, and $\mathrm{CON}$ were $3.2 \pm 1.2,6.3 \pm 1.5,5.9 \pm 0.9$, $6.5 \pm 0.6$, and $7.1 \pm 0.4 \mathrm{mg} \cdot \mathrm{kg}^{-1} \cdot \mathrm{min}^{-1}$, respectively. These rates were similar to those observed when the insulin clamp study was performed without amino acid infusion ( $P=$ NS vs. study 1 for all groups).

\section{Discussion}

The overall incidence of diabetic nephropathy in the diabetic population is $35 \%$ in Western countries (31). All patients who develop proteinuria enter a hemodialysis program or get a kidney transplant within 5-10 years (32). Isolated kidney transplantation is still the first choice surgical approach for type 1 uremic-diabetic patients (33). One of the major drawbacks of isolated kidney transplant is the need to continue life-long therapy with prednisone $\left(10 \mathrm{mg} \cdot \mathrm{d}^{-1}\right)$, cyclosporine ( 5 $\left.\mathrm{mg} \cdot \mathrm{kg}^{-1} \cdot \mathrm{d}^{-1}\right)$, and azathioprine $\left(1 \mathrm{mg} \cdot \mathrm{kg}^{-1} \cdot \mathrm{d}^{-1}\right)$ in insulindependent diabetic patients $(13,34)$. During the last two decades the improvement of both patient and organ survival has made it possible to extend pancreas transplant, alone or in combination with the kidney to a greater number of patients (34). In fact, both segmental and total pancreas transplantation are capable of maintaining long-term insulin indepen-

Table V. Metabolic and Kinetic Parameters of K-Tx and CU during Combined Hyperinsulinemia-Hyperaminoacidemia

\begin{tabular}{|c|c|c|c|c|}
\hline & \multicolumn{2}{|c|}{ K-Tx } & \multicolumn{2}{|c|}{$\mathrm{CU}$} \\
\hline & Bas & Stu & Bas & Stu \\
\hline Patients (n) & 4 & & 4 & \\
\hline $\mathrm{Hb}_{\mathrm{Alc}}(\%)$ & $7.8 \pm 0.5^{*}$ & & $5.8 \pm 0.4$ & \\
\hline Plasma glucose $(\mathrm{mg} / \mathrm{dl})$ & $120.7 \pm 10.8^{*}$ & $95.5 \pm 3.6$ & $84.7 \pm 3.6$ & $88.3 \pm 3.7$ \\
\hline \multirow[t]{2}{*}{ Plasma leucine $(\mu M)$} & $104 \pm 8$ & $207 \pm 23^{\ddagger}$ & $110 \pm 9$ & $209 \pm 17^{\ddagger}$ \\
\hline & \multicolumn{4}{|c|}{$\mu \mathrm{mol} \cdot \mathrm{m}^{-2} \cdot \mathrm{min}^{-1}$} \\
\hline ELF $_{\text {leu }}$ & $37.8 \pm 1.1$ & $19.9 \pm 0.9^{\ddagger}$ & $37.5 \pm 0.5$ & $22.3 \pm 1.1^{\ddagger}$ \\
\hline $\mathrm{ELF}_{\text {kic }}$ & $54.0 \pm 2.6$ & $39.3 \pm 5.4^{\ddagger}$ & $56.8 \pm 2.1$ & $45.9 \pm 5.2^{\ddagger}$ \\
\hline $\mathrm{LO}_{\text {leu }}$ & $6.9 \pm 0.9$ & $35.6 \pm 1.2^{\ddagger}$ & $7.0 \pm 1.1$ & $33.2 \pm 1.0^{\ddagger}$ \\
\hline $\mathbf{L O}_{\text {kic }}$ & $9.9 \pm 1.4$ & $50.9 \pm 3.6^{\ddagger}$ & $10.6 \pm 2.2$ & $51.4 \pm 3.8^{\ddagger}$ \\
\hline NOLD $_{\text {leu }}$ & $30.9 \pm 1.2$ & $40.1 \pm 2.7^{\ddagger}$ & $30.5 \pm 1.9$ & $45.3 \pm 2.9^{\ddagger}$ \\
\hline NOLD $_{\text {kic }}$ & $44.1 \pm 2.9$ & $54.2 \pm 5.4^{\ddagger}$ & $46.2 \pm 2.7$ & $60.7 \pm 5.1^{\ddagger}$ \\
\hline $\mathrm{NLB}_{\text {leu }}$ & $-6.9 \pm 0.9$ & $20.2 \pm 2.0^{\ddagger}$ & $-7.0 \pm 1.1$ & $23.0 \pm 2.0^{\ddagger}$ \\
\hline NLB $_{\text {kic }}$ & $-9.9 \pm 1.4$ & $14.9 \pm 0.8^{\ddagger}$ & $-10.6 \pm 1.9$ & $14.8 \pm 1.1^{\ddagger}$ \\
\hline
\end{tabular}

Data are expressed using both the leu and $\alpha$-KIC specific activities.

${ }^{*} P<0.01$ compared to CU. ${ }^{\ddagger} P<0.01$ compared to basal. 
dence $(1-10$ years $)(13,35)$. In addition, previous studies have demonstrated that transplantation of the pancreas along with the kidney has a better impact on the quality of life of insulindependent diabetic patients compared with transplantation of the kidney alone $(36,37)$.

In the present study we used labeled leucine to assess basal and insulin-stimulated whole body protein metabolism in IDDUP before and after isolated kidney transplant or combined pancreas and kidney transplant. Our data demonstrate that the combination of diabetes mellitus and uremia causes a serious impairment of the basal and insulin-stimulated protein metabolism, that kidney transplant only partially reverts the protein/ metabolic alterations of IDDUP, and finally, that the combination of the replacement of the kidney and the pancreas leads to a near normalization of whole-body protein metabolism, despite the need of chronic immunosuppressive therapy.

The nitrogen excretion rate was significantly higher in the basal state in IDDUP compared to the other groups. This indicated a negative nitrogen balance before transplantation which was reverted by combined kidney and pancreas transplantation (Table I). The protein content of the diet was comparable in IDDUP, in K-Tx alone, and in KP-Tx. Therefore, the difference in nitrogen excretion rate was not attributable to a difference in diet. Transplanted kidney may present a relapse of diabetic nephropathy. In such cases, in order to prevent the progression of renal damage a low-protein diet should be administered (38). A recent report by Brodsky et al. (39) has shown that a low protein diet may cause an impairment of leucine metabolism and a worsening of nitrogen balance and nutritional parameters. Therefore, a possible advantage of performing the transplant of the pancreas along with the kidney is that it is not necessary to give a protein restricted diet to IDDM patients after the transplant and during chronic prednisone administration.

In a previous report we showed that IDDM in poor metabolic control is characterized by increased basal ELF (proteolysis), LO, and NOLD (an index of protein synthesis) (4). The amelioration of the metabolic control by optimizing conventional insulin therapy normalized basal ELF, NOLD, and LO in IDDM subjects (4). The basic defect in protein metabolism in type 1 diabetes mellitus would therefore seem to be a primary increase in proteolysis. In addition, in IDDM, the stimulation of protein synthesis by combined hyperinsulinemia/hyperaminoacidemia is similar to that in normals. In contrast, we have previously shown that patients with chronic uremia are characterized by reduced amino acid concentrations and reduced proteolysis (ELF), LO, and NOLD (8). In the same study, the primary defect in chronic uremia was found to be at the level of protein synthesis, while insulin action on proteolysis was found to be normal. Previous reports had shown that hemodialytic therapy (40) and chronic ambulatory peritoneal dialysis (41) are not capable of normalizing protein turnover and insulin action in uremic patients. Possible explanations of the particularly low ELF and NOLD in postabsorptive IDDUP when compared to controls include the following: $(a)$ increased insulin levels with respect to normals $(8),(b)$ increased growth hormone concentration (Table II), and (c) increased epinephrine concentration. In particular both high insulin (4, 6 ) and growth hormone (42) concentrations have been linked to the low leucine fluxes. We have previously shown that epi- nephrine infusion in normals causes a mild decline of amino acid concentrations (43). From the present results it seems that IDDUP patients demonstrate intracellular defects localized both at the proteolytic and proteosynthetic pathways. This explains the striking negative nitrogen balance in such patients. Apparently both the anti-proteolytic and the proteosynthetic defects are acquired. Insulin deficiency is the primary cause of increase of proteolysis in fasting IDDM (4); when IDDM patients develop uremia a new defect in protein synthesis may be selectively determined. During exogenous insulin infusion (study 1) the inhibition of ELF is defective in IDDUP compared to the other groups indicating an insulin resistance with respect to the proteolytic pathway, only when diabetes mellitus and uremia are combined. During study 2 the stimulation of protein synthesis was defective in IDDUP compared to all the other groups. Therefore, the higher nitrogen excretion rate present in IDDUP is due partially to a defective inhibition of proteolysis and partially to a defective stimulation of the protein synthetic pathway by insulin. The combination of both defects makes more amino acid nitrogen available for the intracellular oxidative processes.

Patients after successful kidney transplant have to continue conventional insulin therapy with the additional problem of chronic immunosuppressive drugs. Furthermore, Nair et al. (44) have recently shown that hyperglucagonemia in combination with insulin deficiency ( the hormone-metabolic condition in diabetic patients after isolated kidney transplant) accelerates protein catabolism. In such patients (K-Tx) the basal ELF is similar or increased with respect to normals depending upon the degree of insulinization. Patients with successful pancreas and kidney transplant are insulin independent and are capable of overcoming the alterations determined by the steroid therapy on glucose metabolism by means of basal and post-prandial hyperinsulinemia $(9,10,12,35,45)$. During study 1 (insulin infusion) the defect of endogenous leucine flux (proteolysis) of IDDUP is reverted in K-Tx. In contrast, insulin-induced inhibition of the leucine oxidative pathway is still defective in $\mathrm{K}$-Tx. Therefore, isolated kidney transplant may revert most of the intracellular metabolic pathways, with the notable exception of insulin-stimulated suppression of LO. This finding may be due to a direct glucocorticoid activation of muscle branched-chain $\alpha$-ketoacid dehydrogenase (46). The fact that $\mathrm{K}-\mathrm{Tx}$ have an absolute value of NOLD similar to CON and higher than KP-Tx during hyperinsulinemia may be explained as follows: $(a)$ patients with isolated kidney transplant are generally insulin resistant as regards whole body leucine metabolism, although the impaired insulin action reaches statistical significance only for LO; in contrast, patients with combined pancreas and kidney transplantation apparently have an increased insulin sensitivity in the protein metabolic pathways; (b) considering the variation from basal instead of the absolute value of NOLD, only in IDDUP the decrease is significantly lower than CON; $(c)$ in order to correct for the fall in amino acids, the best assessment of protein synthetic capacity is obtained in a condition of combined hyperinsulinemia/hyperaminoacidemia (4).

In our 14 patients after combined kidney-pancreas transplantation, we found a clear-cut dissociation between insulin effects on glucose and protein metabolism. In fact, after combined transplantation glucose metabolism is impaired, while 
insulin-stimulated protein metabolism is normal. We had already found this in IDDM (4) and in patients with chronic renal failure (8). The presence of a dissociation between glucose and protein metabolism indicates a postreceptor defect in insulin action (47). From a clinical standpoint this finding supports the fact that the alterations of protein metabolism are easier to correct than the alterations of glucose metabolism by intensified insulin therapy, and by pancreas transplantation itself, in IDDM.

When the pancreas was transplanted along with the kidney a complete reversal of all defects in basal and insulin-stimulated protein metabolism was obtained. In particular, stimulation of NOLD after combined hyperinsulinemia/hyperaminoacidemia was reduced in the diabetic-uremic group compared to controls. This alteration was completely normalized by the combined kidney and pancreas transplantation, indicating that the defect of the protein synthetic pathway is also reversible. Interestingly, also the transplantation of kidney alone was capable to revert the defect in protein synthetic rate during hyperaminoacidemia.

The increased basal insulin concentration present in the kidney-pancreas transplanted group may be determined by increased secretion or reduced clearance of the molecule. Previous reports by Diem et al. (11), Osei et al. (48), and Blackman et al. (49), indicate a reduction of insulin clearance by the liver as the leading cause of basal hyperinsulinemia in KP-Tx. A reduction of insulin clearance is also present in diabetic-uremic patients ( 50 ) as a consequence of impaired renal function. An additional cause of increased basal insulin concentration is the denervation of the transplanted pancreas. In recent works by ourselves (29) and by Blackman et al. (49), it has been shown that the denervated pancreas has an increased basal insulin secretion rate, along with a defective insulin-insulin autoinhibition. Therefore, a strict linkage exists between the basal insulin concentration and the basal concentrations and leucine flux of all study groups. This is underlined by a close statistical correlation between the basal insulin level and the basal endogenous leucine flux $(r=-0.64 ; P<0.05)$ in normal volunteers, in patients with CU and in patients after KP-Tx. This finding indicates that the basal proteolysis is mainly influenced by the insulin concentration, independently of the group of subjects considered. In contrast, when the insulin and ELF of patients of groups 1 and 3 (who were on exogenous insulin administration) were plotted, no correlation was found $(r=0.01 ; P$ = NS).

Hyperinsulinemia has been elsewhere shown to cause deleterious effects on glucose, lipid, and lipoprotein metabolism (51-53). However, Homan et al. (54) have shown in the dog that peripheral insulin delivery (causing hyperinsulinemia) does not induce any major defect on glucose, protein and palmitate metabolism. Although the question of whether hyperinsulinemia is metabolically deleterious is still unanswered, our results support the hypothesis that pancreas transplantation can completely correct the post-receptor alterations induced by diabetes and uremia on protein metabolism.

It is also important to note that the hyperinsulinemia of pancreas transplanted patients is only in the systemic circulation and not in the portal blood. Actually, pancreas transplant recipients might also have a portal hypoinsulinemia when compared to normals. In addition, the systemic hyperinsuline- mia after transplantation is for no matter worse than iatrogenic hyperinsulinemia of the pre-transplant condition.

Prednisone $(55,56)$ cyclosporine A (57), and azathioprine (58) have deleterious effects on whole-body and muscle protein metabolism. In particular, steroids have been shown to mainly stimulate protein breakdown and amino acid oxidation and to directly antagonize insulin action at the muscle site; cyclosporin and azathioprine have been shown to inhibit, with different mechanisms, intracellular protein synthesis. Since all organ transplantations require a long-term administration of these drugs, caution should be used when an organ has to be transplanted in a recipient who might suffer particularly from the effect of these drugs. An important example is found in children and adolescents who have to undergo isolated kidney transplantation $(59,60)$. On the basis of our results the lowdose chronic immunosuppressive therapy does not appear to have a major effect on protein metabolism in IDDM patients or in patients with chronic uveitis. In fact, also during combined hyperinsulinemia/hyperaminoacidemia, CU patients showed a normal stimulation of protein synthetic rate. To note that the results obtained in patients with chronic uveitis are also relevant for other organ transplantations, such as liver and heart, and indicate that the immunosuppressive therapy at the doses used after a transplant does not significantly affect wholebody protein homeostasis $(59,60)$. A possible counteraction of hyperinsulinemia might explain the lack of deleterious effects of chronic immunosuppression in pancreas transplanted patients. In fact, previous work has shown a close correlation between height velocity and basal insulin concentration in diabetic children $(61,62)$ postulating a major role of chronic lowdose hyperinsulinemia on the stimulation of protein synthesis.

The basal epinephrine concentration of our transplanted patients is slightly higher than previously published work (12). This is probably due to the different analytical technique utilized by us (HPLC vs. radioenzymatic).

In conclusion, we have shown that the alterations of basal and insulin-stimulated protein metabolism found in diabeticuremic patients can be completely reverted by combined kidney-pancreas transplantation despite the chronic immunosuppressive therapy. The present data indicates the usefulness of transplantation of the pancreas along with the kidney in diabetic-uremic patients, especially in all clinical and pathophysiological conditions characterized by a higher rate of whole-body protein turnover.

\section{Acknowledgments}

We wish to thank Mrs. Paola Sandoli and Miss Sabrina Costa for their skilled technical assistance. Dr. Karine Winter-Beatty was of invaluable help in preparing the manuscript for this article.

The present work was supported by grants from San Raphael Scientific Institute (D.2/3), University of Milan and the Consiglio Nazionale delle Ricerche, Italy.

\section{References}

1. Felig, P., J. Wahren, R. S. Sherwin, and G. Palaiologes. 1977. Amino acid and protein metabolism in diabetes mellitus. Arch. Intern. Med. 137:507-513.

2. Kopple, J. D. 1978. Abnormal amino acid and protein metabolism in uremia. Kidney Int. 14:340-348. 
3. May, R. C., A. S. Clark, M. A. Goheer, and W. E. Mitch. 1985. Specific defect in insulin mediated muscle metabolism in acute uremia. Kidney Int. 28:490-497.

4. Luzi, L., P. Castellino, D. C. Simonson, A. S. Petrides, and R. A. De Fronzo. 1990. Leucine metabolism in IDDM. Role of insulin and substrate availability. Diabetes. 39:38-48.

5. Nair, K. S., J. S. Garrow, C. Ford, R. F. Mahler, and D. Halliday. 1983 Effect of poor diabetic control and obesity on whole-body protein metabolism in man. Diabetologia. 25:400-403.

6. Tessari, P., R. Nosadini, R. Trevisan, S. Vigili de Kreutzenberg, S. Duner, C. Marescotti, A. Tiengo, and G. Crepaldi. 1986. Defective suppression by insulin of leucine and alpha-KIC metabolism in type 1 diabetes. J. Clin. Invest. 77:17971804.

7. Berkelhammer, C. H., J. P. Baker, L. A. Leiter, P. R. Uldall, R. Whittall, A Slater, and S. L. Wolman. 1987. Whole-body protein turnover in adult hemodialysis patients as measured by ${ }^{13} \mathrm{C}$-leucine. Am. J. Clin. Nutr. 46:778-789.

8. Castellino, P., A. Solini, L. Luzi, J. Grant-Barr, D. J. Smith, A. S. Petrides, and R. A. DeFronzo. 1992. Glucose and amino acid metabolism in patients with chronic renal failure. The effect of insulin and amino acids. Am. J. Physiol. 262:F168-F176.

9. Sutherland, D. E. R., J. S. Najarian, B. Z. Greenberg, B. J. Senske, G. E. Anderson, R. S. Francis, and F. C. Goetz. 1981. Hormonal and metabolic effects of a pancreatic endocrine graft: vascularized segmental transplantation in insulindependent diabetic patients. Ann. Intern. Med. 95:537-41.

10. Östman, J., J. Bolinder, R. Gunnarsson, C. Brattstrom, G. Tyden, J. Wahren, and C.-G. Groth. 1989. Metabolic effects of pancreas transplantation on metabolic and hormonal profiles in IDDM patients. Diabetes. 38(Suppl. 1):8893.

11. Diem, P., M. Abid, J. B. Redmon, D. E. R. Sutherland, and R. P. Robertson. 1990. Systemic venous drainage of pancreas allografts as an independent cause of hyperinsulinemia in type 1 diabetic recipients. Diabetes. 39:534-540.

12. Diem, P., J. B. Redmon, M. Abid, A. Moran, D. E. R. Sutherland, J. B. Halter, and R. P. Robertson. 1990. Glucagon, cathecolamine and pancreatic polypeptide secretion in type 1 diabetic recipients of pancreas allografts. J. Clin. Invest. 86:2008-2013.

13. Luzi, L., A. Secchi, F. Facchini, A. Battezzati, C. Staudacher, D. Spotti, R. Castoldi, G. Ferrari, V. Di Carlo, and G. Pozza. 1990. Reduction of insulin resistance by combined kidney-pancreas transplantation in type 1 (insulin-dependent) diabetic patients. Diabetologia. 33:549-556.

14. Landgraf, R., M. M. C. Landgraf-Leurs, D. Burg, A. Kampik, L. A. Castro, A. Abendroth, W. D. Illner, and W. Land. 1986. Long-term follow up of segmental pancreas transplantation in type 1-diabetes. Transplant. Proc. 18:1118-1124.

15. Groth, G. C., H. Collste, G. Lundgren, H. Wilczek, G. Klintmalm, O. Ringden, R. Gunnarsson, and J. Ostman. 1982. Successful outcome of segmental human pancreatic transplantation with enteric exocrine diversion after modification in technique. Lancet. ii:522-524.

16. Coward, W. A., S. A. Parkinson, and P. R. Murgatroyd. 1988. Body composition measurements for nutrition research. Nutr. Res. Rev. 1:115-124.

17. Spotti, D., M. C. Librenti, M. Melandri, G. Slaviero, R. Quartagno, P. Vedani, V. Tagliabue, and G. Pozza. 1993. Bioelectrical impedance in the evaluation of the nutritional status of hemodialyzed patients. Clin. Nephrol. 39:172174.

18. Abumrad, N. N., D. Rabin, M. P. Diamond, and W. W. Lacy. 1981. Use of an heated superficial vein as an alternative site for the measurement of amino acid concentrations and for the study of glucose and alanine kinetics in man. Metab. Clin. Exp. 30:936-940.

19. Allsop, J. R., R. R. Wolfe, and J. F. Burke. 1978. Tracer priming the bicarbonate pool. J. Appl. Physiol. 45:137-139.

20. Simonson, D. C., and R. A. DeFronzo. 1990. Indirect calorimetry: methodological and interpretative problems. Am. J. Physiol. 258:E399-E412.

21. Castellino, P., L. Luzi, D. C. Simonson, W. M. Haymond, and R. A. De Fronzo. 1987. Effect of insulin and plasma amino acid concentration on leucine metabolism in man. J. Clin. Invest. 80:1784-1793.

22. Nissen, S. L., C. Van Huysen, and M. W. Haymond. 1982. Measurement of branched chain amino acids and branched chain alpha-ketoacids by HPLC. $J$. Chromatogr. 232:170-175.

23. Waterlow, J. C., P. J. Garlick, and D. J. Millward. 1978. Protein Turnover in Mammalian Tissues and in the Whole Body. North-Holland, Amsterdam. $227 \mathrm{pp}$.

24. Irving, G. S., W. W. Wong, R. J. Shulman, E. O'Brian Smith, and P. D. Klein. 1983. $\left[{ }^{13} \mathrm{C}\right]$ bicarbonate kinetics in humans:intra-vs interindividual variations. Am. J. Physiol. 245:R190-R202.

25. Irving, G. S., W. W. Wong, W. M. Wong, W. Boutton, R. J. Shulman, C. L. Lifshitz, E. W. Malphus, H. Helge, and P. D. Klein. 1984. Rapid determination of whole body bicarbonate kinetic by use of a digital infusion. Am. J. Physiol. 247:R709-R716.
26. Schwenk, W. F., I. B. Beaufrere, and M. W. Haymond. 1981. Use of reciprocal pool specific activities to model leucine metabolism in man. Am. J. Physiol. 240:E630-E639.

27. Cobelli, C., M. P. Saccomani, P. Tessari, G. Biolo, L. Luzi, and D. E. Matthews. 1991. Compartmental model of leucine kinetics in humans. Am. J. Physiol. 26:E539-E550.

28. Ripamonti, M., A. Mosca, E. Rovida, M. Luzzana, L. Luzi, F. Ceriotti, F. Cottini, and L. Rossi-Bernardi. 1984. Urea, creatinine and glucose determined in plasma and whole blood by a differential-pH technique. Clin. Chem. 30:556-559.

29. Luzi, L., A. Battezzati, G. Perseghin, E. Bianchi, S. Vergani, A. Secchi, E. LaRocca, C. Staudacher, D. Spotti, G. Ferrari, et al. 1992. Lack of feed-back inhibition of insulin secretion in denervated human pancreas. Diabetes. 41:1632-1639.

30. Glantz, S. A., and B. K. Slinker. 1990. Primer of Applied Regression Analysis of Variance. McGraw Hill, Inc., New York. 777 pp.

31. Krolewsky, A. S., J. H. Warram, A. R. Christlieb, E. J. Bunsick, and C. R. Kahn. 1985. The changing natural history of nephropathy in type 1 diabetes. $A m$. J. Med. 78:785-794.

32. Viberti, G. C., R. W. Bilous, D. Makintosch, and H. Keen. 1983. Monitoring glomerular function in diabetic nephropathy: a prospective study. Am. J. Med. 74:256-264.

33. Lindholm, A., D. Albrechtsen, G. Tufveson, I. Karlberg, N. H. Persson and G.-C. Groth. 1992. A randomized trial of cyclosporine and prednisolone vs cyclosporine, azathioprine and prednisolone in primary cadaveric renal transplantation. Transplantation. 54:624-632.

34. Brayman, K. L., and D. E. R. Sutherland. 1992. Factors leading to improved outcome following pancreas transplantation. The influence of immunosuppression and HLA matching. Transplant Proc. Suppl. 2:91-95.

35. Katz, H., M. Homan, J. Velosa, P. Robertson, and R. Rizza. 1991. Effects of pancreas transplantation on post-prandial glucose metabolism. N. Engl. J. Med. 325:1278-1284.

36. Corry, P., and P. Zeher. 1990. Quality of life of diabetic recipients of kidney transplants is better with the addition of the pancreas. Clin Transplantation. 4:238-241.

37. Voreganti, L. N. P., and R. A. Sells. 1989. Quality of life of diabetic patients after combined pancreatic-renal transplantation. Clin. Transplant. 3:7882.

38. Zeller, K., E. Whittaker, L. Sullivan, and P. Raskin. 1991. Effect of restricting dietary protein on progression of renal failure in patients with IDDM. $N$. Engl. J. Med. 324:78-84.

39. Brodsky, I. G., D. C. Robbins, E. Hiser, S. P. Fuller, M. Filliaw, and J. T. Devlin. 1992. Effect of low-protein diets on protein metabolism in IDDM patients with early nephropathy. J. Clin. Endocrinol. Metab. 75:351-357.

40. Schrieber, M., S. Kalhan, A. McCullogh, and S. Savin. 1985. Branched chain amino acid metabolism in chronic renal failure and hemodyalisis. Proc. Eur. Dial. Transplant. Assoc. 22:116-120.

41. Castellino, P., R. A. De Fronzo, and C. Giordano. 1987. Glucose metabolism and insulin sensitivity in CAPD patients. Periton. Dial. Bull. Suppl. 7:22

42. Barrett, E. J., and D. A. Fryburg. 1992. Growth hormone acutely stimulates forearm muscle but not whole-body protein synthesis in humans. Diabetes. S1 187A. (Abstr.)

43. Castellino, P., L. Luzi, S. DelPrato, and R. A. De Fronzo. 1990. Dissociation of the effect of epinephrine and insulin on glucose and protein metabolism. Am. J. Physiol. 258:E117-E125.

44. Nair, K. S., D. Halliday, D. E. Matthews, and S. L. Welle. 1987. Hyperglucagonemia during insulin deficiency accelerates protein catabolism. Am. J. Physiol. 253:E208-E213.

45. Secchi, A., J. M. Dubernard, E. La Rocca, M. Melandri, N. Lefrancois, X. Martin, J. L. Touraine, J. Traeger, and G. Pozza. 1991. Endocrino-metabolic effects of whole vs segmental pancreas allotransplantation in diabetic patients: a two year follow up. Transplantation. 51:625-629.

46. Haber, R. S., and S. P. Weinstein. 1992. Role of glucose transporters in glucocorticoid-induced insulin resistance: glut 4 isoform in rat skeletal muscle is not decreased by dexamethasone. Diabetes. 41:728-735.

47. Caro, J. F., and J. M. Amatruda. 1982. Glucocorticoid-induced insulin resistance: the importance of post-receptor events in the regulation of insulin binding and degradation. J. Clin. Invest. 69:866-875.

48. Osei, K., M. L. Henry, T. M. O’Dorisio, R. J. Tesi, B. G. Sommer, and R. M. Ferguson. 1990. Physiological and pharmacological stimulation of pancreatic islet hormone secretion in type 1 diabetic pancreas allograft recipients. Diabetes. 39:1235-1242.

49. Blackman, J. D., K. S. Polonsky, J. B. Jaspan, J. Sturis, E. V. Canter, and J. R. Thistlewaite. 1992. Insulin secretory profiles and C-peptide clearance kinetics at 6 months and 2 years after kidney-pancreas transplantation. Diabetes. 41:1346-1354.

50. Linn, V.S., S. C. Kathpalia, and C. Henriquez. 1978. Endocrine abnormalities associated with chronic renal failure. Med. Clin. North Am. 62:1341-1362. 
51. Rizza, R., L. J. Mandarino, J. Genest, B. A. Baker, and J. E. Gerich. 1985 Production of insulin resistance by hyperinsulinemia in man. Diabetologia. 28:70-75.

52. Groop, L. C., R. C. Bonadonna, M. Shank, A. S. Petrides, and R. A. DeFronzo. 1991. Role of free fatty acids and insulin in determining free fatty acid and lipid oxidation in man. J. Clin. Invest. 87:83-89.

53. Bagdade, J. D., and F. L. Dunn. 1992. Effect of insulin treatment on lipoprotein composition and function in patients with IDDM. Diabetes. 41 (Suppl. 2):107-110.

54. Homan, M., C. P. Nicholson, H. Katz, J. Perkins, M. W. Haymond, M. Jensen, P. Butler, and R. Rizza. 1991. Effects of chronic systemic insulin delivery on insulin action in dogs. Diabetologia. 34:702-708.

55. Tomas, F. N., H. N. Munro, and V. R. Young. 1979. Effect of glucocorticoid administration on the rate of muscle protein breakdown in rats as measured by urinary extraction of N-methylhistidine. Biochem. J. 178:139-146.

56. Dahlmann, B., M. Rutschmann, and H. Reinauer. 1986. Effect of starvation or treatment with corticosterone on the amount of easily releaseable myofilaments in rat skeletal muscles. Biochem. J. 234:659-664.
57. Scherrer, U., S. F. Vissing, B. J. Morgan, J. A. Rolliu, R. S. A. Tindall, S. Ring, P. Hanson, P. K. Mohanty, and R. G. Victor. 1990. Cyclosporin-induced sympathetic activation and hypertension after heart transplantation. $N$. Engl. $J$ Med. 323:693-699.

58. Nashel, D. J. 1985. Mechanisms of action and clinical applications of cytotoxic drugs in rheumatic disorders. Med. Clin. North Am. 69:817-840.

59. Starnes, V. A., E. S. Stinson, P. E. Oyer, H. Valantine, J. C. Baldwin, S. A. Hunt, and N. E. Shunmay. 1987. Cardiac transplantation in children and adolescents. Circulation. 76:V43-47.

60. Ettenger, R. B., C. Blifeld, H. Prince, D. B. Bradus, S. Cho, N. Sekiya, I. B. Salusky, and R. N. Fine. 1987. The pediatric nephrologists' dilemma: growth after renal transplantation and its interaction with age as a possible immunologic variable. J. Pediatr. 111:1022-1025.

61. Leslie, R. D. G., S. Lo, A. B. Millward, J. Honour, and D. A. Pyke. 1991 Decreased growth velocity before IDDM onset. Diabetes. 40:211-216.

62. Hindmarch, P. C., D. R. Matthews, L. DiSilvio, A. B. Kurtz, and C. G. D. Brook. 1988. Relation between height velocity and fasting insulin concentrations. Arch. Dis. Child. 63:665-666. 